\title{
IQTISHODUNA
}

IQTISHODUNA: Jurnal Ekonomi Islam

E-ISSN: 2443-0056, P-ISSN: 2252-5661

Accredited Number 21/E/KPT/2018

Volume 9 Issue 1, April 2020 | Page: 105-120

DOI: doi.org/10.36835/iqtishoduna.v9i1.474

\section{The Model of Islamic Boarding School Economic Development In Hidayatullah Islamic Boarding School Mataram City and Darussalam West Lombok}

\author{
Mawardi Saleh", Lalu Agus Satriawan² \\ 1,2Departement of Sharia Economics, Faculty of Islamic Economics and Business, Universitas \\ Islam Negeri Mataram, Jl. Pendidikan No.35 Dasan Agung Baru Kec. Selaparang Kota Mataram \\ Nusa Tenggara Barat 83125, Indonesia \\ e-mail: ${ }^{1}$ mawardisalehyani@uinmataram.ac.id ${ }^{2} \underline{\text { la_satriawan@uinmataram.ac.id }}$
}

\begin{abstract}
In its historical setting pondok pesantren (islamic boarding school) present in the form of traditional educational institutions whose activities are more focused on the study of religious books and the organization of religious education. But since the 1970s Islamic boarding school began to evolve and organize public education, involved in social activities even in the economic field. Witnessing this phenomenon, it was felt necessary to conduct a study of the Islamic boarding school economic development model in pondok pesantren Hidayatullah, Mataram City and pondok pesantren Darussalam in West Lombok. The focus of the study is twofold: the potentials of the pondok pesantren and the Islamic boarding school economic development model. The results of the study are: (1) The economic potentials owned by Hidayatullah and Darussalam boarding schools are the leadership, students, teachers and education activities, (2) The economic development model carried out by Hidayatullah and Darussalam is an integrated model realized in the form of a top down model and bottom up the model that both models work by combining the strength of the leadership element with the strength of the element of asatidz and santri
\end{abstract}

Keywords: model, economic development, islamic boarding school

Abstrak: Dalam seting sejarahnya pesantren hadir dalam bentuk lembaga pendidikan tradisional yang kegiatannya lebih terfokus pada kajian kitab agama dan penyelenggaraan pendidikan keagamaan. Tapi sejak tahun 1970 an pesantren mulai berevolusi dan menyelenggarakan pendidikan umum, terlibat dalam kegiatan sosial bahkan pada bidang ekonomi. Menyaksikan fenomena tersebut, maka dirasa perlu melakukan kajian tentang model pengembangan ekonomi pesantren di PP Hidayatullah Kota Mataram dan PP Darussalam Lombok Barat. Fokus penelitian ada dua yaitu potensi-potensi pesantren dan model pengembangan ekonomi pesantren. Adapun jenis penelitian ini adalah penelitian kualitatif deskriptif dan metode pengumpulan data yang digunakan adalah observasi, wawancara dan dokumentasi. Hasil penelitian yaitu 1) Potensi-potensi ekonomi yang dimiliki oleh pesantren Hidayatullah dan Darussalam adalah kefiguran pimpinan, santri, para asatidz dan kegiatan pendidikan, 2) Model pengembangan ekonomi yang dilakukan Hidayatullah dan Darussalam adalah integrated model yang diwujudkan dalam bentuk top down model dan bottom up model yang kedua model tersebut bekerja dengan memadukan antara kekuatan unsur pimpinan dengan kekuatan unsur asatidz dan santri.

Kata Kunci: model, pengembangan ekonomi, pesantren

\section{Introduction}

In the structure of national education, Islamic boarding school is a very important chain. This is not only because of its relatively long history of emergence, but also because Islamic boarding school significantly contribute to the effort 
106 IQTISHODUNA: Jurnal Ekonomi Islam Volume 9 Issue 1, April 2020

to educate the nation's life. Historically, Islamic boarding school are community-based educational institutions ${ }^{1}$. The existence of Islamic boarding schools has proven to have a very large role in the history of the struggle of the Indonesian people. Islamic boarding schools became the basis for moving people with an Islamic spirit in the context of expelling invaders. Islamic boarding schools have proven their existence and progress as dynamic agents in every process of struggle and national development. Its work, not only as an educational institution, but also an institution of struggle, social, economic, diversity, culture and propaganda ${ }^{2}$.

History records, since the beginning of the existence of Islam in Indonesia, Islamic boarding school have emerged together with the history of trade, then developed and penetrated the Islamic education and propaganda sector, and ended in power. Power is formed or usurped solely as a tool to secure and develop the economic sector with the education sector ${ }^{3}$.

Compared to the partial education environment offered by the public school education system in Indonesia today, Islamic boarding schools have a unique culture. Because of its uniqueness, Islamic boarding schools are classified into separate subcultures in Indonesian society.

\footnotetext{
1Yacub, Hamzah, Pondok Pesantren dan Pembangunan Masyarakat Desa, (Bandung: Angkasa, 2006). 2Jurnal Ekonomi dan Bisnis Islam | Vol. IX, No. 1, Desember 2014

3Jurnal Ekonomi Syariah Indonesia Volume I, No. 2 Desember 2011
}

More than five thousand Islamic boarding schools spread in sixty eight thousand villages, is separate evidence to declare it as a subculture. This uniqueness also in turn can produce enormous economic value if managed professionally.

The social and economic progress of a Islamic boarding school is inseparable from the role of the students (santri). Head master (Kiai) and (Ustadz) have charismatic power that is able to control students in carrying out socio-economic activities. In managing the Islamic boarding school farming business, the kiai only provides guidance, the rest is the responsibility of the santri. The challenges facing Islamic boarding schools are increasingly large, complex and urgent, as a result of the increasing need for development and advancement of knowledge and technology. This challenge caused a shift in values in Islamic boarding school, both values related to learning resources and values related to management of education, shifts in learning systems and methods, as well as shifts in the development of the Islamic boarding school's institutional functions themselves. ${ }^{4}$

Facts show that in the context of NTB, competition in the micro sector, such as home industry, culinary, service sector including traveling in the last three years has begun to show a fairly high constellation. Of course this fact must be seen as a positive phenomenon that requires all human

4Perspektif Sosiologi, Vol. 4, No 1, Januari 2016, Hal. 58. 
resources $(\mathrm{SDM})$ in this area must prepare themselves and social institutions including religious institutions such as Islamic boarding school to be able to respond to these changes and developments. In this framework, human resources produced by Islamic boarding school are expected to not only have a more integrative and comprehensive scientific perspective between the fields of religious sciences and worldly sciences but also have certain practical abilities needed in today's competition, especially in the business world.

To realize that, the need for boarding school efforts in developing the economic potential of Islamic boarding school in the form of business charities that can make Islamic boarding school more economically independent and improve the quality of pesantren education. That basis the researcher conducted a study through research entitled "The Model of Islamic Boarding School Economic Development in Hidayatullah Islamic Boarding School in Mataram and PP Darussalam Tanak Beak, West Lombok, West Nusa Tenggara. There are two important things that will be examined in this study, namely assessing the potential possessed and the economic development model carried out by the two boarding schools. The expected benefit of research is to be able to discover the economic potentials of the two huts and get clarity on the models of economic development conducted by the
Islamic Boarding School Hidayatullah and Darussalam. Conception of Islamic Boarding School

The majority of the views of the experts, that the Islamic boarding school is a traditional institution engaged in the field of traditional education that still maintains learning of classical books. However, if we look at the potential and development of Islamic boarding school today, as said by Azyumardi Azra, pesantren are now expected to no longer simply play their traditional functions, namely; "Transmission and transfer of Islamic sciences, maintenance of Islamic traditions, reproduction of ulama", but also a center for health counseling, a center for developing appropriate technology for rural communities, a center for efforts to save and preserve the environment; and more importantly become the center of community economic empowerment and its surroundings. Therefore, the function of the Islamic boarding school is not only as a center for the cadre of clerics (Kiai), human resources (SDM), but is also expected to be an institution that can empower the community (agent of development) itself 5 .

\section{Potentials of Islamic Boarding Schools}

Islamic boarding school as a media identifies and develops various potentials of the Islamic boarding school community so that it appears to be a force. Some potentials intended are:

5Jurnal Hukum Islam (JHI) Volume 12, Nomor 1, Juni 2014, STAIN Pekalongan. 
108 IQTISHODUNA: Jurnal Ekonomi Islam

Volume 9 Issue 1, April 2020

a. Master Tecaher (Kiai/Tuan Guru) Master Teacher (Kiai, Tuan Guru) is a figure that is the most essential element in boarding schools. Tuan Guru is a person who leads a Islamic boarding school with high charisma, diligent worship and extensive and deep religious knowledge. Therefore, the Masters, besides giving religious lessons and being the spiritual leaders of their students, are not infrequently also "psychosomatic doctors" and are magnets for the community. The kiai (master teacher) is the holder of doctrinal religious sciences. This task cannot be delegated to the general public because it relates to the belief that the ulema are the heirs of the Prophet. In this way, how the uniqueness of the leadership of the teacher in this Islamic boarding school can be seen as a potential Islamic boarding school that has economic value.

b. Student (Santri)

The second economic potential inherent in Islamic boarding school is santri, or students. This self-potential analysis must be understood, that the students often have innate potential / talents, such as the ability to read the Qur'an, calligraphy, carpentry, and so on. This innate talent should always be nurtured and developed. For this reason, it is better if Islamic boarding school are applied in tracking the potential / talents and interests of students, then fostered and trained ${ }^{6}$.

\section{Methodology}

The type of research used is descriptive qualitative. Descriptive is an analysis conducted by describing data that aims to uncover the facts in the field. The research was conducted at Hidayatullah Islamic Boarding School in Mataram City and Darussalam Islamic Boarding School Tanak Beak, West Lombok. While the source of the data were all Islamic boarding school elements which were used as research informants, namely 1) master teacher, 2) foundation management, 3) teacher as manager 4) student, 5 ) the manager of each charity business and 6) the employees of each charity business.

Data collection methods used are:

\section{a. Observation}

The purpose of observation is to describe the observed environment, the activities that take place, the individuals involved in the environment along with the activities and behaviors that appear, and the meaning of events based on the views of the individuals involved. Researchers conducted observations on the potential possessed by both boarding schools and observed the economic development models carried out by each of the charity businesses owned by boarding schools.

b. Interview

Interview is defined as an interaction in which there is a conversation between two people, one of which aims to explore and obtain information for a particular purpose. In qualitative research there are three types of interviews, namely structured interviews, semi-

${ }^{6}$ A. Halim, “Menggali, hal. 227. 
Boarding School Mataram City dan Darussalam West Lombok

structured interviews, and unstructured interviews. Respondents interviewed were 1) master teacher, 2) foundation management, 3) teacher as manager 4) student, 5) manager of each business charity and 6) employees of each business charity.

c. Dokumentation

The documentation technique is used by collecting data from archives related to the location of the pesantren, photographs of activities in each charity business.

\section{Data Analysis}

In this interactive analysis model according to Miles Hubermant as quoted by Sugiyono in his book that interactive analysis consists of ${ }^{31}$ :

Data Reduction

Reducing data means summarizing, choosing the main points, focusing on the things that are important, looking for themes and patterns and removing unnecessary. Thus the data that has been reduced will provide a clearer picture, and make it easier for researchers to do further data analysis, and look for it if needed.

1. Data Presentation

After the data has been reduced, the next step is displaying data or presenting data, which is a collection of arranged information that gives the possibility of drawing conclusions and taking action. By presenting data, researchers can understand what is happening and what must be done based on an understanding of data presentation.
Drawing Conclusions

The conclusions drawn are handled loosely and remain open so that conclusions that were initially unclear, then increase to become more detailed and firmly rooted. This conclusion was also verified during the research with the intention of testing its validity, robustness and suitability which is its validity. Thus, in this stage the flow of efforts and implementation of the santri economic empowerment are measured, as well as the benefits of such economic empowerment.

\section{Result and Discussion}

\section{A Brief History of Hidayatullah Islamic Boarding School}

According to the explanation of Ust Abidin7, after Ust. Abdullah Said (founder) died in 1998, Hidayatullah's leadership was continued by Ust. Abdurrahman Muhammad. Then not long after that the Executive Board was formed which was tasked with holding a national meeting to determine the direction and form of Hidayatullah going forward. Through the first National Conference on 9-13 July 2000 in Balikpapan, Hidayatullah officially changed its form to a social organization (organization) with 5 levels of management, namely the central, regional, regional, branch and branch branches.

\footnotetext{
${ }^{7}$ Chairperson of Al Iman Foundation Islamic Boarding School Hidayatullah Mataram, interview, 18 July 2019.
} 
110 IQTISHODUNA: Jurnal Ekonomi Islam

Volume 9 Issue 1, April 2020

Basic Principles of Hidayatullah Islamic Boarding Scool

Do not request

Accroding to Ust Pardin', The principle of not request for its purpose, all members of Hidayatullah are not permitted to carry out actions (any effort whatsoever) in order to obtain certain positions in the management structure or any function. It is not permissible for anyone to approach and take certain paths through parties or officials in Hidayatullah to get the position they want. In this case, Hidayatullah taught to all that the position and position is a mandate that not everyone is able to carry it, so that the ability of each person will be determined by the authorities (leader of the foundation) based on the results of the assessment and performance shown.

\section{Do not refuse}

Then the principle of not refuse the intention is that every member of Hidayatullah who is given the mandate carries the task of the organization, then he must accept it. Any assignment of any form or type, wherever the place is, whenever and whatever conditions it faces, the member is obliged to accept that assignment (unless there are shar'i reasons) which does not allow him to carry out the mandate. Fardin gave an example, he himself is now entrusted to become the Deputy of Curriculum in MADAYA (Madrasah Aliyah Hidayatullah)

8Pardin, Deputy head of Madrasah Aliyah and Chair of the Mataram Hidayatullah Cooperative, interview, 20 July 2019. since 2015. While in the cooperative, the chairman who had previously resigned because he became an advisory team in the structure of the foundation of Iman Hidayatullah taught that the position and assets need not be pursued. moreover sought after in various ways even perform actions that are not justified syar'i. Obligations and tasks that must be done is to work earnestly, maximum endeavor, willing to accept everything that is available from each of these maximum endeavors and of course remain diligent in carrying out these endeavors.

\section{Praiseworthy Attitude}

Since the students entered the Islamic boarding school, they began to be introduced to several principles that must be held and followed in their daily activities, including about the students' praiseworthy attitudes toward themselves and others. Praiseworthy attitude is the most important foundation that is instilled by this cottage to all its students in all levels, from the lowest to the highest. It is not permissible between students to be sentimental, socially jealous, suspect or demean other students. Islamic boarding schools instill that the status of all students in the cottage is the same, no one should feel to be a child.

\section{Potentials of Islamic Boarding School}

Hidayatullah boarding school in Mataram is certainly an inseparable part of the existence of the central Hidayatullah boarding school in Balikpapan. Hidayatullah boarding school in Mataram is an organization 
structure or boarding school Hidayatullah which is at the regional or provincial level. Hidayatullah Islamic boarding school was first established by Ust Abdullah Ihsan in 1992. The link with the economic potential possessed by the Hidayatullah Islamic boarding school Mataram is not much different from the potential developed at the central level. However, not all economic potentials at the central level are exactly the same as those at regional and regional levels. Until now, according to Ust Fardin ${ }^{9}$ the economic potential possessed by the Islamic boarding school Hidayatullah Mataram can be in the form of educational institutions, economic business institutions, social fields and human resources.

\section{Field of Education}

In the principle of business and long-term investment, especially for the safety of life in the afterlife, the education sector is one of the types of business charity managed by Hidayatullah. In managing this charity, the education business is carried out with the principles of awareness by all elements of the manager, the principle of openness, a sense of responsibility, fair and certainly professional. In the field of education, the Islamic Boarding School Hidayatullah manages educational institutions with the concept of "integral character of monotheism". Educational institutions managed in the Hidayatullah Islamic Boarding
School in Mataram starting from PAUD, TK, SDIT, MTs and Hidayatullah Senior High School.

In the 2019/2020 school year, for the TK / PAUD level Hidayatullah managed 7 study groups (groups A and B) totaling 208 students, there were 17 study groups at SDIT with a total of 612 santri, Yunior high school and SMA / Hidayatullah Senior High School (MADAYA) levels. each numbered 6 classes. So that the total number of students who took education from PAUD / TK to MA in Hidayatullah amounted to around 1,142 people.

\section{Field of Economic}

In the economic field, the Hidayatullah Islamic boarding school is very much promoting business units (charitable business). Likewise, what was said by Ust Rozi10 the potential of the Hidayatullah Islamic boarding school is:
a. Cooperative
b. Canteen
c. Benefaction Store

\section{Human Resources}

Hidayatullah

Islamic boarding school Mataram has human resources that thank God can be counted on to be invited to fight. For us, all of our friends depart from the intention to join together in educating and fostering generations and Muslims, especially through educational institutions, social and economic institutions. Human Resources recruitment in Hidayatullah began to take shape

\footnotetext{
${ }^{10}$ Ust Fahrurrozi, Treasurer of $\mathrm{Al}$ Iman PP Hidayatullah Foundation, interview, July 20, 2019.
} 
112 IQTISHODUNA: Jurnal Ekonomi Islam Volume 9 Issue 1, April 2020

through natural selection since they attended education or studied at Hidayatullah. At the end of their education, especially those who graduated from Madrasah Aliyah / Senior High School, some of them will be chosen by the foundation to be able to participate in the service at least one year before they continue their studies. They will be placed in all business institutions Hidayatullah both in educational institutions, propaganda, economic, social and media. They will also be distributed to all regions and branches that need personnel in each institution. So this is where the principle in Hidayatullah applies that every candidate for management / servant must not ask and may not refuse any position and where placed.

\section{Figure/Leader}

In terms of the island of Lombok, the religious figure is embedded as the master teacher. The existence of a master teacher for the people of Lombok is very high and glorified because he has high religious knowledge and a figure of religious experts who is istiqomah and patient in the struggle to uphold and convey religious teachings to his people. A master teacher has a regular congregation or recitation assembly and usually leads a boarding school. The study assemblies are scattered in almost all directions on the island of Lombok, or there are also teachers who only have study assemblies around the sub-district and regency, even the recitation is only done in their own homes and not opened outside. Specifically for the context of the Hidayatullah Islamic boarding school in Mataram, the term 'Tuan Guru' is not popular. However, the title of leader or figure is quite simply called the cleric, in fact almost as the cleric is used by all the teacher councils and the cleric for female teachers. In relation to the role and responsibility as a leader in managing educational institutions, da'wah and economic institutions, Ustadh Abidin (leader of the al Iman Hidayatullah boarding school foundation) prioritizes manhaj and propaganda principles held in the Islamic boarding school Hidayatullah namely the movement to instill tawheed awareness, foster fraternity and foster fraternity and morals of the Qur'ani, improve spiritual quality, awaken the missionary movements and realize perfect Islam.

To show their existence as a leader, can be heard and used as an example by their congregation, he just needs to enforce it with strength, sincerity, patience and istiqomah over all the above manhaj in all dimensions of life and relationships, then the other management and guardians of students will provide the mandate high level to manage and manage assets and potential possessed by Islamic boarding school. With this mandate, a leader can easily and freely utilize the potential of the Islamic boarding school to develop and in the end will have a positive impact on the progress of the Islamic boarding school.

\section{Students and Student Education}

According to Ust Zohdi's explanation, the next economic potential that is attached to the 
Boarding School Mataram City dan Darussalam West Lombok

Hidayatullah Islamic boarding school in Mataram is the santri or students. The number of student owned by Hidayatullah Islamic boarding school is 820 people, becoming a great potential and capital to develop the Islamic boarding school economy very openly. This analysis of self-potential must be understood, that the students often have innate potential / talent. This innate talent we always fertilizer and develop. For this reason, we trace the potential / talents and interests of students, then be nurtured and trained. In terms of making student as an asset and potential for Islamic boarding school economic development, it can be illustrated that with the number of TK / PAUD santri as many as 208 people by giving an infaq as large as Rp. 200,000 / santri / month, funds will be collected every month around $208 \times 200,000=41,600,000 /$ month . Santri SDIT 612 people with an amount of Rp. 350,000 / santri / month, funds will be collected every month around $612 \times 350,000=$ $214,200,000$ / month. So the total infaq received by Hidayatullah Islamic boarding school every month was Rp. 255,800,000. The amount is certainly large enough to be managed and used as capital to develop existing business charities in pesantren such as educational institutions, cooperatives, canteens and other business charities.

As mentioned above, one of the uniqueness of Islamic boarding schools lies in its integral education system. That is, the educational model typical of Islamic boarding schools, such as non-classical sorogan 11, combined with modern classical education models. In addition, the disciplines he practiced were not only religious knowledge, but also other general subjects, such as English, mathematics, sociology, anthropology, and so on. For the smooth learning process, a set of books, books and stationery are needed. From here, one of the Islamic boarding school business units that can provide such learning facilities, such as bookstores or books, stationery, and photocopies, not to mention their daily needs such as eating and drinking, water, telephone, dormitory, clothing, and so. The economic potential of the education sector is certainly more perfect when combined with students' self potential as explained in point two. The problem is just how all this potential is managed professionally, but still displays the characteristics of boarding schools. This is one of the challenges of Islamic boarding schools and educational institutions in Islamic boarding schools.

The economic potential of the education sector is certainly more perfect when combined with students' self potential as explained in point two. The problem is just how all this potential is managed professionally, but still displays the characteristics of boarding schools. This is one of the challenges of Islamic boarding school and its

11 Zamakhsyari Dhofier, Tradisi Pesantren studi tentang Pandangan Hidup Kiai (Jakarta: LP3ES, 1994), hal.28-33. 
114 IQTISHODUNA: Jurnal Ekonomi Islam Volume 9 Issue 1, April 2020

educational institutions. Because of that, it takes managerial courage from caregivers to color the management of Islamic boarding schools in a more professional and modern way, but it is typical of boarding schools. In this context, the inheritance of a Tuan Guru-ulama, is not only seen from the religious aspect, but also other aspects, such as the insight and managerial of Tuan Guru.

\section{The model of Hidayatullah Islamic Boarding School Economic Development}

Ustadz Fardin said that to create a formidable and creative boarding school people, then as a basis for economic development, it needs to be done with the following principles and patterns:

\section{Trust Building}

Every boarding school resident in Hidayatullah is trustworthy and responsible. They will be given open opportunities to carry out activities such as:

a. The teachers innovate in extracurricular activities

b. Make innovations in designing arts performance activities, graduation of students and scientific debate activities.

c. Creating various types of businesses that can bring added value economically to the cottage and increase students' entrepreneurial skills.

d. For students to innovate in designing art activities and other student activities.

\section{Homely/Uncomplicated}

The leaders of the Islamic boarding school set an example that the manager of the boarding school was not given an individual luxury while serving as administrators and residents of the cottage, because that attitude would damage the mandate given by the guardians of the students and the community.

Positive Image/Husnudzdzon

According to the explanation of Ust Abidin (leader of the Hidayatullah Islamic Boarding School in Mataram), Hidayatullah residents were given the understanding that to build a resilient community and high commitment, everyone needs to do a positive image for themselves. All the noble qualities (siddiq, amanah, tabliq, fathonah) in the Messenger of Allah must become a global ethic to be emulated in everyday life, especially when undergoing the mandate that is pinned to him. That is the color in the life of the Prophet. $\mathrm{He}$ is not a rich man, but since childhood he appeared with full responsibility and trust when given the task to accompany a wealthy widow woman, Siti Khadijah ra. That basis Khadijah put extraordinary sympathy on the personality of the Prophet so he chose the Prophet to be a companion and leader of his life despite his age (25 years) far below the age of Khadijah (40 years). And when he was 40 years old he was successful and did not take care of business anymore because his family's needs were met and he continued to pray in the cave hiro 'to receive a trust that is far greater than Allah SWT is the command to convey the truth of Islam.

Likewise, the same incident when the event of Hajarul Aswad was released from the Ka'bah, all tribes in conflict felt that their tribe had the 
most right to raise the Hajarul Aswad back to the Ka'bah. But it was precisely Muhammad who they agreed to choose to mediate and provide solutions so that all the tribes accepted the decision. It was all based because the Prophet had a positive image in front of all the Quraysh tribes.

So the concept of capital (money and capital) in Islam does not really exist, the existing capital is siddiq, amanah, tablig, fathonah. If people have given high trust to us, whatever we ask, people will not be difficult to give the mandate. That is the basis and capital for Hidayatullah to build and develop institutions so that students, teachers, guardians of students easily accept the offer of the program that we submit because they see the concrete evidence that we provide, even investors such as banks easily offer capital to Hidayatullah and finally from ICT.

\section{Open Management}

In every activity carried out by both the teacher council and the santri, Hidayatullah opens the same opportunities and opportunities for anyone individually or as a group to create as much as possible by promoting the principle of open management. Several activities carried out by the board of teachers and students In 2016 Hidayatullah sent 10 teachers to Jakarta facilitated by Bank Indonesia for entrepreneurship and cooperative training. The aim is to increase knowledge, skills and confidence for teachers in managing businesses in Hidayatullah as well as in businesses managed by teachers themselves.
The concept of business management and management in the Hidayatullah Islamic boarding school is that there should be no monopoly of capital (private shares) from anyone in all business units, both by the management and the family of the foundation. This means that from a number of business units managed by Hidayatullah, the system cannot be acquired (evaluated) by the foundation's family, such as school principals at every level of education, all based on the principle of openness and objectivity, anyone who academically and professionally meets the requirements and is considered capable, he is which is mandated to be the head. Management should not be directly held by the boarding school family. Likewise with cooperatives, mart stalls and laundry. That's why every pesantren's income and income through one door is the head of the boarding school which is then distributed openly to all units that need it by submitting a budget plan in advance.

\section{Principles of Productivity}

Hidayatullah also holds the principle of productivity. Every financial report at the end of the year is given a zero balance. The head of the Islamic boarding school advises all implementing elements of each activity that the financial accountability report should not leave money in the books, because if there is a balance, it means you are corrupt. We know that Islamic boarding schools always have more ideas than money. If there is money 
116 IQTISHODUNA: Jurnal Ekonomi Islam

Volume 9 Issue 1, April 2020

left over, then that means there are pesantren boarding programs that you don't live and that don't educate in an effort to develop boarding schools.

\section{Darussalam Tanak Beak Narmada Islamic Boarding School}

The Model of Islamic Boarding

School Economic Development

For the Daarussalam Islamic boarding schools, does not yet have a model of Islamic boarding schools economic development that can be proud of because this pesantren is relatively new. This Islamic boarding schools also in practice of education the students still go home and go from their homes. This means that up to now the Islamic boarding schools has not provided lodging / boarding facilities for students, but we are currently working on them. For us, we have the concept of providing a dormitory with a different (unique) design, such as a berugak model with 2 floors and separate berugak (rooms) from one another. This concept was raised with the thought that if the students who memorized their notes would join the main program is tahfiz, then a relatively comfortable place would be needed especially at the edge of the rice fields so that students would be more comfortable living in the dormitory for memorization programs.

In addition, Daarussalam Tanak Beak Islamic boarding school has a unique program called Tabungan Hajj Umrah Cinta Ka'bah. This program began running about 3 years ago (2015) which was designated for guardians of students and residents of surrounding communities in the villages of Tanak Beak, Lekong Siwak and Kerama Jaya Village, Narmada District. Savers categories are mostly farmers, traders in the Narmada market, artisans, laborers and teachers. This program is unique because every community or anyone has the same opportunity to perform Hajj and Umrah. The trick is that the community can save just a few, starting from Rp. 10,000, - 20,000, 50,000 , some even Rp. 100,000 per saving time, and they have an account book and hold it themselves. And the most important thing is the people in the doctrine that the pilgrimage or Umrah does not have to sell land as happened in some communities, or the poor can easily also go up. Until now there are residents whose savings have reached Rp. 20,000,000

\section{The Model of Hidayatullah Islamic Boarding School Economic Development}

From the study conducted by researchers through interviews and observations, it was observed that the model used by Hidayatullah Islamic boarding school in developing the economic capacity of Islamic boarding schools is the integrated system model. According to ust Fardin and the foundation's leadership, this system (integrated system model) is a combination of a top down system and a bottom up system. This means that in the management and economic development of Islamic boarding schools the leadership element combines the potential possessed by 
the leadership elements both at the top level of the leadership and those in the fields or sub-fields with the potential possessed at the level of asatidz and santri. the model system is a strength for Hidayatullah pesantren to build the capacity of the pesantren which is one of the objectives of the pesantren establishment.

The form of the Integrated system model is:

\section{Topdown model}

For boarding school leaders to understand about the top down model is a management model that bases on planning and starts from the leadership level by identifying and mapping all potentials and opportunities owned by the pesantren. Planning with a "top down planning" system means that planning is carried out by the highest institution in the boarding school environment as the initial idea giver and plays a more dominant role in regulating the course of the program to be developed in the boarding school. In carrying out planning, program implementation, supervision up to the evaluation stage the foundation leadership has a very central and strategic role, while the existence of asatidz and santri is not much involved.

As a consequence of this model, the existence of teachers and students cannot play a more active role because the role of foundations is more dominant when compared to the role of teachers and students themselves. Teachers and students cannot see how far a program has been implemented. The role of teachers and students is only as a recipient of decisions or results of a program without knowing the course of the process of forming the program from beginning to end, so that the processes and dynamics that are formed cannot be directly followed by the teachers and students. In this case the ideas, potential and creativity of the teachers and students cannot be directly demonstrated.

In applying this model the foundation's leaders use it in several activities such as:

a. Determination of Infaq value from educational business charity

At Hidayatullah Islamic boarding school the existence of educational institutions as central in the management of financial resources and all other charitable business financing. Ust Azadin explained that educational institutions were the source of the institution's income, and then the donation or infaq capital would be distributed to all business charities under the guidance of Hidayatullah Islamic boarding school..

b. Determination of the infaq distribution direction

c. Determination of priorities for development direction

The advantages of this system are: The community does not need to work and provide input the program has been able to run alone because of the optimal role of government.

The results can be optimal because the costs incurred are borne by the government. 
Optimizing the performance of government workers in organizing a program.

a. Bottom up model

Planning with a system "bottom up planning" means that the planning is carried out in which the teacher and students have more role in giving initial ideas to evaluate the programs that have been carried out while the leadership of the foundation has more role as a facilitator in the course of the program.

Planning with a combined system of the two systems above is planning arranged based on the needs of boarding school residents, especially teachers and students and the program desired by them can improve the quality of boarding school management.

b. Internal Pattern

Potential students and teachers deployed directly to manage various business units in Islamic boarding schools. This model does not rely on theory alone, but they learn while working and when finding errors there they will read the existing provisions and immediately correct them. All the charitable businesses owned by Hidayatullah functioned as educational institutions. Educational institutions are a source of infaq revenue which is then managed by other business charities such as cooperatives, laundry and canteens. When the institution utilizes all the potential of the Islamic boarding school and finally can contribute a number of profits per month that becomes the acceptance of the boarding school.

\section{Types of Business Hidayatullah}

From the results of interviews with Ust Fardin and the results of documentation coverage, researchers found many data related to the type or line of business in the Hidayatullah Islamic boarding school, Mataram, namely:

\section{Hidayatullah Cooperative}

From an interview with Ust Fardin, the Hidayatullah cooperative was a business that was engaged in providing all the daily needs of students or boarding school residents. These items include stationery, toiletries and washing, various snacks, various drinks, books, headscarves, reading books and souvenirs. Wayan Istiqomah was also given the mandate to be responsible by the leadership of the Islamic boarding school so that the Hidayatullah cooperative could run smoothly and provide satisfying service. The consumers of the Hidayatullah cooperative are students, teachers and guardians of students. The normal daily sales value can reach 3,000,000 - 4,000,000, but on certain days such as the visit of the guardians of students and PSB can penetrate 5,000,000 per day. In taking profits, Hidayatullah cooperatives set prices below the general price with a profit interval of $10-15 \%$ of the price of the goods, and it depends on the high and low prices of the goods. Then related to the hour of service is not done all day, but the Hidayatullah cooperative is open when the students are resting at 05.30-07.00, 10.00-10.30, 13.00-13.30, 15.30.16.15 and 20.00-22.00, except for full Friday open from morning - night 
when the guardian of santri comes to visit. And from the Hidayatullah cooperative can contribute to the boarding school at least 30 million / month.

\section{Hidayatullah Canteen}

Hidayatullah canteen also provides various types of food and drinks. However, the cafeteria is specialized in selling ready-made wet food, various fried foods, mixed rice, various drinks and various types of fast food. The canteen also has a turnover of around 1,000,000 everyday, but if it is Friday (during the visit of the guardians of students) the canteen will get a turnover of up to 1.5 million on that day.

\section{Conclusion}

From the findings in the field related to the economic potential of boarding schools that indeed Hidayatullah has 4 potential sources, namely educational institutions, students, figures and economic institutions. All of these potentials become the main capital of Islamic boarding schools in developing the economy and become capital to develop and improve the quality of Islamic boarding schools. Then the economic development model carried out by Hidayatullah Islamic boarding school is an integrated model that is a top down and bottom up model.

\section{REFERENCES}

Ahmad Faozan. Pondok Pesantren dan Pemberdayaan Ekonomi. Ibda',| Vol. 4, No. 1, Jan-Jun 2006.
Fahrurrozi (Bendahara Yayasan Al Iman Pondok Pesantren Hidayatullah), interview, on July 20, 2019.

Hadari Nawawi. 1998. Metode

Penelitian Bidang Sosial.

Yogyakarta: Gajah Mada

University Press.

Haris Herdiansyah, Metodologi Penelitian Kualitatif.

Jurnal Ekonomi dan Bisnis Islam | Vol. IX, No. 1, Desember 2014

Jurnal Ekonomi Syariah Indonesia Volume I, No. 2 Desember 2011

Jurnal Hukum Islam (JHI) Volume 12, Nomor 1, Juni 2014, STAIN Pekalongan.

Ketua Yayasan Al Iman Pondok Pesantren Hidayatullah Mataram, wawancara, tanggal 18 Juli 2019.

Pardin, Wakamad Madrasah Aliyah dan Ketua Koperasi Hidayatullah Mataram, wawancara, tanggal 20 Juli 2019.

Perspektif Sosiologi, Vol. 4, No 1, Januari 2016, Hal. 58.

Sugiyono. 2009. Metode Penelitian Pendidikan (Pendekatan Kualitatif, Kuantitatif dan $R \mathcal{E}$ $D)$. Bandung: PT. Alfabeta. 
120 IQTISHODUNA: Jurnal Ekonomi Islam Volume 9 Issue 1, April 2020

Yacub, Hamzah. 2006. Pondok Pesantren dan Pembangunan Masyarakat Desa. Bandung: Angkasa.

Zamakhsyari Dhofier. 1994. Tradisi Pesantren studi tentang Pandangan Hidup Kiai. Jakarta: LP3ES.

Supriyandi. Prosiding Seminar Nasional Penyuluhan Pembangunan 2016. Program Studi Magister dan Doktor Penyuluhan Pembangunan/ Pemberdayaan Masyarakat, Pascasarjana Universitas Sebelas Maret Surakarta

Sugiyono. 2009. Metode Penelitian Pendidikan (Pendekatan Kualitatif, Kuantitatif dan $R \mathcal{E}$ D. PT. Alfabeta

Amin Haidari, dkk. 2004. Masa $\begin{array}{lcr}\text { Depan } & \text { Pesantren } & \text { dalam } \\ \text { Tantangan } & \text { Modernitas } & \text { dan } \\ \text { Tantangan } & \text { Kompleksitas } & \text { Global, } \\ \text { Jakarta: } & \text { IRD } & \text { Press. }\end{array}$ 